\title{
Thomas S. Kuhn und das Interview
}

\author{
Anke te Heesen
}

Humboldt-Universität zu Berlin, Institut für Geschichtswissenschaften, Unter den Linden 6, 10099 Berlin

anke.te.heesen@hu-berlin.de

\section{Das Bild}

Im Frühsommer 1963 erscheint eine Photographie von Thomas S. Kuhn in einer dänischen Tageszeitung (Abb. 1). Es zeigt den Wissenschaftshistoriker an einem Schreibtisch sitzend. Mit der obligatorischen Zigarette in der Hand geht er lässig die vor ihm liegenden Unterlagen durch. Es handelt sich weniger um die Aufnahme eines erfolgreichen, aus dem akademischen Milieu stammenden Professors, als vielmehr um die eines Papierarbeiters: Das Telefon ist als störendes Element in den Hintergrund gerückt, der Flüssigkleber steht in einer großen Dose in der rechten Bildhälfte bereit, Klebeband wie Heftklammerapparat sind am vorderen Schreibtischrand platziert und Papiere umgeben den Mann. Es handelt sich um kein repräsentatives Wissenschaftlerportrait, dafür ist der auf dem Bildausschnitt erscheinende Arbeitsraum zu ungeordnet, ist $\mathrm{zu}$ viel von der Heizung im Hintergrund zu sehen: Jemand arbeitet etwas durch und schaut kurz hoch, als er angesprochen wird.

Diese Aufnahme vom Juni 1963 ist die bisher einzige, die Kuhn als Leiter des Sammlungs- und Interviewprojekts Sources for History of Quantum Physics zeigt. Das Projekt, von der National Science Foundation gefördert und 1961

* Dieser Text ging aus verschiedenen Vorträgen hervor, die ich 2014 und 2015 in den Kolloquien des Doktoratskollegs „The Sciences in Historical, Philosophical and Cultural Contexts“ der Universität Wien, des Instituts für Medizin- und Wissenschaftsgeschichte der Universität zu Lübeck, im Herbstprogramm des Forschungszentrums Gotha der Universität Erfurt, der Wissenschaftsgeschichte am Institut für Philosophie, Literatur-, Wissenschafts- und Technikgeschichte der Technischen Universität Berlin und am Forschungszentrum Historische Geisteswissenschaften der Universität Frankfurt am Main gehalten habe. Von den intensiven Diskussionen und den hilfreichen Kommentaren habe ich sehr profitiert. Besonders danken möchte ich Stephan Orendi für seine Unterstützung bei den Recherchen und Skúli Sigurdsson und Dieter Hoffmann für ihre vielfältigen Hinweise und Fragen. Eine Monographie zur Entstehung des Projekts Sources for History of Quantum Physics und der Stellung des Interviews in den $1960 e r$ Jahren ist in Vorbereitung. 


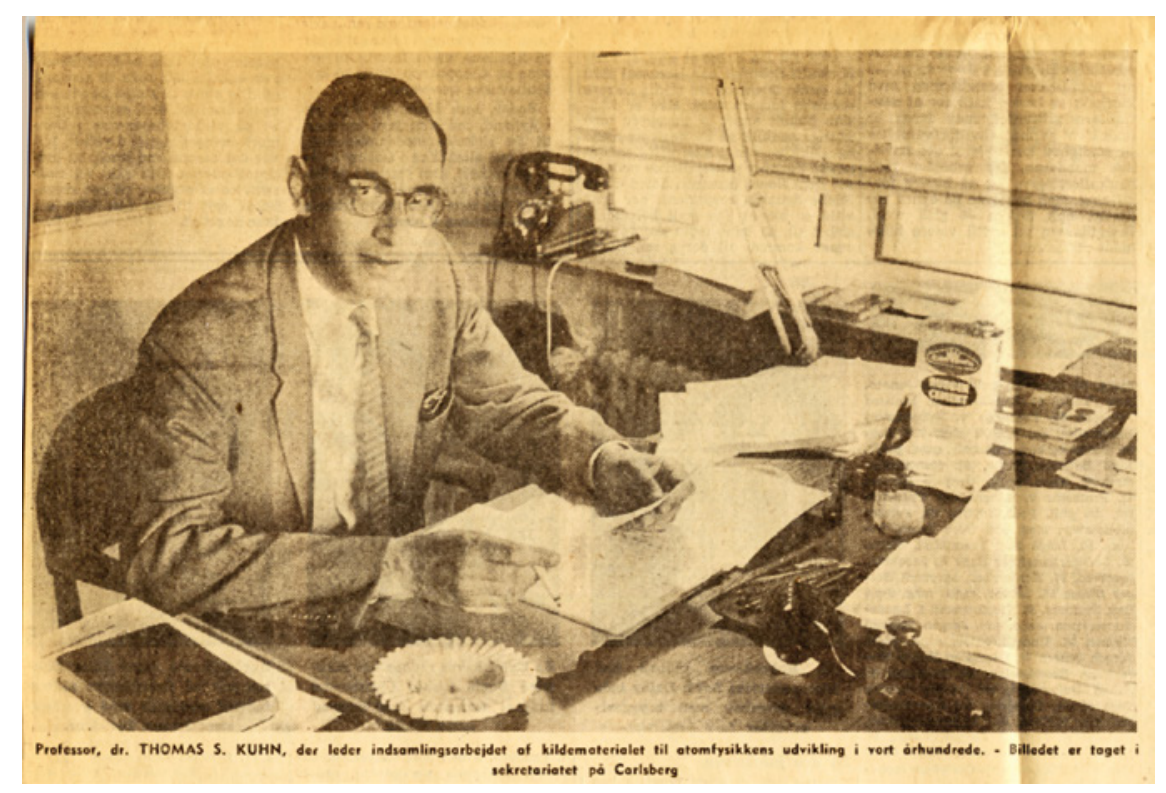

ABB. 1

Thomas S. Kuhn am Schreibtisch in Kopenhagen 1963

offiziell begonnen, hatte zum Ziel, alle verfügbaren Quellen zu der Entwicklung und den Anfängen der Quantenphysik zu sammeln. Dazu sollten die noch lebenden Physiker und Physikerinnen ausführlich interviewt und zu ihren Erinnerungen wie ihren noch existierenden persönlichen Unterlagen befragt werden. Es ist nicht mehr zu ermitteln, welche Unterlagen Kuhn auf dem Bild durchgeht. Sind es Kopien von unveröffentlichten Manuskripten, vielleicht auch von Briefen, oder sind es Typoskripte einer Interviewsitzung? Klar ist, dass die Sammlung des Papiermaterials im Vordergrund stand. Dem Zeitungsleser wurde Kuhn nicht in einer repräsentativen Interviewsituation vorgestellt, sondern mit einer Sammlung von und in der Arbeit mit Schriftstücken. Der Inhalt des Zeitungsartikels selbst bestärkt diesen Eindruck: In letzter Minute habe man das Material zusammengesucht und Gespräche mit den noch lebenden Physikern geführt. Von Niels Bohr existierten auch viele Stunden Interviewaufzeichnungen, vor allem aber - und dies sei Bohr selbst ein Anliegen gewesen - habe er dem Projekt seine zahlreichen Briefe und Aufzeichnungen zur Kopie überlassen. Nun würden daraus gemeinsam mit weiteren Unterlagen neue Archive gegründet, die in Zukunft für die historische Forschung unabdingbar seien. ${ }^{1}$ Man könnte also argumentieren, dass Kuhn an dieser Stelle

1 Ich danke Emma Hagström Molin, die mir den dänischen Text übersetzt hat. 
auch gar nicht in einem Interview hätte gezeigt werden können, da Bohr zum Zeitpunkt der Aufnahme bereits verstorben war. Doch ein Indiz dafür, dass es sich hierbei nicht allein um eine Perspektivierung des Fotografen handelt oder um besondere Umstände, die das Ablichten eines Interviews verhinderten, gibt eine retrospektive Projektschilderung Kuhns. Als er 1995 ausführlich zu seinem Werdegang befragt wurde, widmete er diesen Projektjahren nur eine knappe Schilderung, bei der er rückblickend die Kärrnerarbeit des Dokumentensammelns als den entscheidenden Teil darstellte, die Interviews aber in den Hintergrund rückte, mehr noch, sie negativ beschrieb: „Interviewing was frustrating as hell!" ${ }^{2}$ Was also hatte es mit den Interviews - nicht abgebildet und in der Erfahrung niederschmetternd - auf sich?

Im Folgenden soll dieser Frage in mehreren Schritten nachgegangen werden. Zunächst geht es darum, die Geschichte des Projekts zu umreißen. Wie war es aufgebaut und welche Erwartungen hatte Kuhn ursprünglich mit dem Projekt verbunden? In einem zweiten Schritt werde ich mögliche Anregungen für den Einsatz von Interviews und ihren Stellenwert um 1960 aufzeigen. Dass dabei die entstehende Oral History eine wichtige Rolle spielt, verwundert nicht, wird aber deutlich machen, welche besonderen Möglichkeiten man in der Frühzeit mit ihr verband. Schließlich werde ich im letzten Teil einen kurzen Ausschnitt aus einem Interview-Transkript vorstellen und daran zeigen, warum es von Kuhn als Höllenritt eingestuft wurde. Interviews, so soll argumentiert werden, wurden nicht als Konglomerat akustischer, visueller und semantischer Teile verstanden, nicht als zu interpretierende Quelle von Berichtetem, tonalem Ausdruck und zu beobachtender Gestik und Mimik, sondern in erster Linie als eine noch nicht ausgeschöpfte unmittelbare Informationsquelle über vergangene Ereignisse, als eine brachliegende und deshalb notwendig zu hebende Ressource zur Geschichte der Physik. Interviews sollten den wissenschaftlichen Forschungsprozess ans Tageslicht befördern und der bis dahin bekannten und klassischen Entdeckungsgeschichte der Daten und einsamen Helden endlich eine Schilderung des Auf und Ab der Forschung, des kollaborativen Austauschs und der Fehler wie Durchbrüche in der Etablierung der neuen Physik zu Beginn des neuen Jahrhunderts bereitstellen. Interviews sollten - so Kuhns Hoffnung - science in the making aufdecken. Dass damit Enttäuschungen einhergingen, verwundert heute nicht.

2 Baltas/Gavroglu/Kindi (2000), S. 303. Seine eigenen knappen Äußerungen spiegeln sich in der Sekundärliteratur wider; die Geschichte des Projekts wird mal mehr, mal weniger ausführlich geschildert (vgl. etwa Fuller [2000], S. 182-186, hilfreich auch Sigurdsson [1990]), bisher ist ihm aber keine ausführliche Untersuchung gewidmet worden. 


\section{Das Projekt}

Die Sources for History of Quantum Physics oder, in der gegenwärtigen Benennung, das Archive for the History of Quantum Physics gilt als einzigartige Quelle der Physikgeschichte, die in kopierter Form in 19 verschiedenen Bibliotheken der Welt zugänglich ist. ${ }^{3}$ Es handelt sich um Mikrofilme mit Kopien von Korrespondenzen der Wissenschaftler, ihren nicht publizierten Manuskripten und Notizbüchern sowie von Transkripten zahlloser Interviews mit den für die Entwicklung der Quantenphysik maßgeblichen Männern und einigen wenigen Frauen. Ausgangspunkt war die Überlegung einiger amerikanischer Physiker Ende der 1950er Jahre, dass die theoretische Physik im Laufe des 20. Jahrhunderts massive Umwälzungen erfahren hatte. Das mechanische Weltbild des 17. Jahrhunderts war um 1900 eingestürzt, als durch die Relativitätstheorie und die Quantenphysik Raum und Zeit neu definiert, bekannte Naturgesetze gegen Kontingenz und Unvorhersagbarkeit ausgetauscht wurden und Berechnungen zu neuen Erkenntnissen führten. Es war die Physik der abstrakten Forschungsmethoden und der neuen Teilchen, die schließlich zur Entwicklung von Atombombe und Kernreaktoren führte und die eine eminente Bedeutung für die ökonomische und politische Entwicklung der Welt nach dem Zweiten Weltkrieg hatte. Ihre Protagonisten lebten noch, hatten Geschichte damit geschrieben, und waren nicht in der dunklen Ferne der Vergangenheit, sondern noch im Licht der Gegenwart zu finden, hießen Niels Bohr oder Peter Debye. Allerdings einte die bekannten wie unbekannteren Wissenschaftler vor allem eins: Sie waren um 1960 und im Planungszeitraum des Projekts in die Jahre gekommen, einige der zentralen Figuren wie Albert Einstein waren bereits verstorben. ${ }^{4}$ Deshalb galt es, ihre Erinnerungen und noch verfügbaren Dokumente zu retten; sie mussten ausfindig gemacht und in gezielten Interviewsessions befragt werden. „However, the decisive developments of interest here - relativity and quantum theory - germinated in the decade-and-a-half, 1898-1913, and rose nearly to their present state and stature during the further two decades, 1913-1933". ${ }^{5}$ So beschreibt John Wheeler, selbst ein theoretischer Physiker und einer der Initiatoren des Projekts, den Inhalt und zugleich die Raison d'Être des Projekts. Vom 1.7.1961 bis zum 31.6.1964 trugen Thomas Kuhn, John Heilbron

3 Vgl. Kuhn/Heilbron/Forman/Allen (1967): Sources for History of Quantum Physics und https://amphilsoc.org/guides/ahqp/ (13.6.2017).

4 Albert Einstein stirbt 1955, Wolfgang Pauli drei Jahre später und Erwin Schrödinger kurz vor Projektbeginn im Januar 1961.

5 Kuhn/Heilbron/Formann/Allen (1967), S. v. 
und Paul Forman das Archiv zusammen. Lini Allen organisierte als Sekretärin das Projekt. Die drei Männer zählten einige Jahre später zu den berühmtesten Wissenschaftshistorikern und veröffentlichten zu dem von ihnen in der Frühzeit ihrer Karrieren zusammengetragenen Archivmaterial. ${ }^{6}$ 1967, drei Jahre nach dem offiziellen Ende des Projekts, wurde eine abschließende, die Mikrofilme begleitende und das erhobene Material erklärende und katalogisierende Veröffentlichung in Buchform herausgegeben. ${ }^{7}$ Eine immense, mit nichts - weder in der damaligen Physik noch in der Wissenschaftsgeschichte - zu vergleichende Arbeit.

Die Einzigartigkeit des Projekts und seine unmittelbare Bedeutung für die sich entwickelnde Wissenschaftsgeschichte in Amerika wird deutlich, wenn man bedenkt, dass hier zum ersten Mal eine Zeitgeschichte der Wissenschaften in großem Maßstab betrieben wurde. ${ }^{8}$ Denn unter History of Scien$c e$ verstand man Ende der 1950er Jahre vor allem die Geschichte der großen historischen Figuren der Wissenschaftlichen Revolution des 17. Jahrhunderts. Deshalb konstatieren die Autoren selbstbewusst und zu Recht: "There is little precedent for this project's attempt rapidly to gather manuscripts and recollections concerning a major episode in the development of modern science." ${ }^{9}$ Ein umfangreiches, auf ein Themenfeld und eine Disziplin spezialisiertes Archiv sollte mit der umfassenden Sichtung allen verfügbaren Materials aufgebaut werden. Eine Universität allein, geschweige denn eine einzelne Bibliothek konnte dies weder finanzieren noch organisieren. So arbeiteten die American Philosophical Society und die American Physical Society zusammen, bildeten ein Joint Committee und beantragten bei der National Science Foundation die notwendigen finanziellen Mittel. Thomas S. Kuhn nahm am 1.7.1961 offiziell seine Arbeit auf, sein Doktorand John Heilbron im Laufe desselben Sommers und sein Student Paul Forman schließlich 1962.

6 Ein Beispiel dafür bildet der gemeinsam von Kuhn und Heilbron verfasste Aufsatz The Genesis of the Bohr Atom (vgl. Heilbron/Kuhn [1969]); vgl. überblickend auch Heilbron (1968).

7 Für Kuhn, Heilbron, Forman und Allen ist das Projekt 1964 abgeschlossen, jedoch wurde eine weitere eingeschränkte Finanzierung gewährt, um über die kommenden Jahre hinweg ergänzende Interviews und Dokumentsammlungen zu ermöglichen. Die Projektleitung wurde Friedrich Hund, einem emeritierten Physiker in Göttingen, übertragen, der selbst an der Entwicklung der Quantenphysik beteiligt gewesen war.

8 Vgl. dazu Carson/Kojevnikov/Trischler (2011), S. 3. Bereits 1978 hebt der Historiker Lutz Niethammer das Projekt als das „vielleicht bedeutendste wissenschaftsgeschichtliche OralHistory-Projekt" hervor, nicht zuletzt deshalb, weil er dort eine abwägende Darstellung der Interviews und ihrer Vor- und Nachteile fand (Niethammer [1978], S. 472).

9 Kuhn/Heilbron/Forman/Allen (1967), S. 1. 
Die Mission bestand aus surveying (Literatur), compiling (Daten), comparing (Biographien und Institutionen), selecting and designing (Interviews). ${ }^{10}$ Bibliographien wurden gewälzt, Bibliotheken angeschrieben, Physiker weltweit um ihre Mithilfe und ihre Kontakte gebeten, Fragebögen verschickt, Zeitschriftenaufrufe gestartet und Listen über Listen erstellt: Von denjenigen, die schon gestorben waren, denjenigen, die noch lebten, aber möglichst bald konsultiert werden müssten und denjenigen, die zu den sichereren Gesprächspartnern gehörten, weil sie noch jung genug erschienen. „The immortality of his [the quantum history, AtH; sic!] heroes is at stake."11 Zahlreiche Physiker sagten ihre Mitarbeit und ihre Bereitschaft zu, interviewt zu werden. Darunter war auch Niels Bohr, der zur Schlüsselfigur für die Recherchen und Interviews mit in Europa lebenden Physikern werden sollte: Im September 1962 zog das Team nach Kopenhagen um und quartierte sich in den von Bohr angebotenen Arbeitsräumen auf dem aufgelassenen Gelände der Carlsberg-Brauerei ein. Bohr und seine Familie waren der Ausgangspunkt für die nun einsetzenden Recherchen. Als Bohr kurz darauf im November 1962 starb, war dies ein einschneidender Moment für das Projekt, denn es verlor einen seiner zentralen Informanten und Kontaktgeber. Dennoch wurden die meisten der etwa 175 Interviews mit 100 Personen in den Jahren 1962 und 1963 geführt. ${ }^{12}$ Das Ausmaß der Transkriptionsarbeit war dementsprechend überwältigend und Paul Forman verbrachte vermutlich die meiste Zeit mit dem Edieren der ersten Transkriptionen und der archivalischen Organisation des Materials. John Heilbron bereitete die Interviews vor, indem er die biographischen und damit verbundenen institutionellen Daten akribisch zusammenführte. Sowohl Kuhn als auch Heilbron stellten Kontakte her und führten die Interviews. Im Sommer 1963 kehrte die Gruppe nach Berkeley zurück. ${ }^{13}$ Im verbleibenden Jahr der Finanzierung wurden letzte Interviews geführt, die Materialien geordnet, in entsprechenden Konvoluten zu einem konsultierbaren Archiv zusammengestellt und auf Mikrofilmen zunächst in den Bibliotheken in Berkeley, Kopenhagen und Philadelphia zur Verfügung gestellt. Die alles zusammenfassende und das Archiv in seiner Struktur darstellende Veröffentlichung, die drei Jahre

10 So die Benennung der zentralen Tätigkeiten, entnommen aus dem ersten Kapitel von ebd., S. 2 f.

11 Ebd., S. vi.

12 Ebd., S. 3.

13 Vgl. American Philosophical Society (im folgenden APS), „Archive for the History of Quantum Physics“ (im folgenden AHQP), BOX 23-530.1AR 2.5: „Second Year-End Report, Oct. 28,1963 “', S. 1. 
später erschien, wurde in ersten Kapitelentwürfen vorbereitet, das Büro an der University of California in Berkeley im Juli 1964 endgültig aufgelöst. ${ }^{14}$

\section{Das Buch}

Blickt man genauer auf dieses umfangreiche, zeitintensive und vor allem personelle Ressourcen verschlingende Projekt, so wird deutlich, dass es sich hier nicht allein um ein in die Karrieren dreier junger Physiker eingeschobenes Sammlungsprojekt zur Überbrückungsfinanzierung handelte, sondern um ein zentrales, das sich wandelnde Verständnis von Wissenschaftsgeschichte um 1960 charakterisierendes Unterfangen. Als Kuhn offiziell im Februar 1961 gefragt wurde, ob er die Leitung des Projekts übernehmen wolle, lehrte er an der University of California in Berkeley „History of Science“. Noch während des ersten Projektjahres schrieb er an seiner Structure of Scientific Revolutions, das Vorwort stellte er erst im Februar 1962 fertig. Zu diesem Zeitpunkt wurde er bereits seit acht Monaten von der National Science Foundation finanziert. Es ist dieses Buch, das den Hoffnungen und Enttäuschungen Kuhns über das Interview vorausgeht. In ihm beschäftigte er sich mit der Frage, wie wissenschaftliche Erkenntnis, wie wissenschaftlicher Fortschritt möglich sei. Hier erweiterte er die historische Rede von der Wissenschaftlichen Revolution, indem er damit nicht nur die historische Phase des 16. und 17. Jahrhunderts gehäufter wissenschaftlicher, das Weltbild wandelnder Erkenntnisse markierte, sondern sie als einen strukturellen und durchaus immer wiederkehrenden Ablauf verstand. Es gibt nicht die eine „Wissenschaftliche Revolution“, sondern viele Phasen, in denen jeweils eine Umwälzung stattfindet. Kuhn legt in seiner Structure of Scientific Revolutions, die er zur Zeit der Abfassung des Antrags in einer ersten Fassung an ausgewählte Kollegen zur Lektüre verschickte, einen Entwurf für die sich immer wieder ereignenden Umbrüche vor. Es kennzeichnete sie in der Weise, dass sie sich weder schnell ereigneten noch von einer einzigen Person initiiert werden konnten, wie es bisherige Entdeckungsgeschichten behauptet hatten. Vielmehr gehe es um ein Zusammenspiel mehrerer Faktoren, deren Definition und zeitliche Abfolge zu klären Kuhn sich zur Aufgabe gesetzt hatte. Ein zentraler Begriff war dabei das „Paradigma“, also eine von der Wissenschaftlergemeinschaft getragene Übereinkunft oder ein Set an Problemlösungen. Ziel seines Buches war es, eine theoretische wie historische

14 Vgl. den Brief Kuhns an die Mitglieder des Beirats vom 4.8.1964; APS, AHQP, BOX 23-530. 1AR 2.5: „Correspondence 1964“, S.2. 
Neuorientierung zu bewirken. Dabei wandte er sich von dem bis dahin zentralen Bild naturwissenschaftlichen Arbeitens und wissenschaftlichen Fortschritts, wie es vor allem der Wiener Kreis und Karl Popper vertraten, ab: Nicht der Dreischritt von Annahme/Hypothese, Experimentieren und schließlich Interpretieren der gewonnenen Daten als der aller (Natur-)Wissenschaft unterliegende planmäßige Forschungsgang, nicht der bewusste rationale Akt eines Wissenschaftlers stehen im Vordergrund seiner Annahmen. Vielmehr ist es eine Gemengelage aus psychischen und sozialen Faktoren, aus Kontingenzen, Irrtümern und Sackgassen, deren historische wie zeitgenössische Betrachtung keinen Anlass bot, von einer geradlinigen, aufstrebenden Wissenschaft zu sprechen. Kuhn geht es um eine neue Geschichte in dem Sinn, dass man sie nicht nur als eine Art Prüfstein für die entsprechende vorherrschende Erkenntnistheorie nutzen solle, sondern auch neue historiographische Wege einschlagen müsse. Von sich selbst schreibt er, dass er viele Jahre an "[der] heute sehr einflußreiche[n] Unterscheidung zwischen ,Entdeckungszusammenhang‘ und ,Begründungszusammenhang'“ festgehalten habe. „Viele Jahre lang glaubte ich, sie beträfen die Natur der Erkenntnis“, doch seine Versuche, sie auf „tatsächliche Situationen, in denen Kenntnisse erworben, anerkannt und assimiliert werden", auch anzuwenden, schlugen fehl. ${ }^{15}$ Nicht von der "Logik der Forschung" wie bei Popper sollte deshalb ausgegangen werden, sondern von der Forschung selbst. Kuhn drehte den Spieß um, indem er nicht die Geschichte der Wissenschaften nach den Maßstäben einer logischen Erkenntnistheorie und von dem Wissensstand der Gegenwart aus bewertete, sondern die Theorie anhand der Geschichte der Wissenschaften zu entwerfen versuchte. Das war das Anliegen seiner Arbeit und dies entwickelte er aus den zahlreichen Fallstudien, die dem Buch vorangegangen waren. Heraus kam dabei eines der einflussreichsten Bücher der Wissenschaftsgeschichte. Zum ersten Mal hatte jemand auf die wissenschaftliche Praxis selbst geblickt und, wo möglich, bereits Briefe und Lebenserinnerungen von Wissenschaftlern gesucht und in seine Überlegungen zu der Struktur wissenschaftlicher Revolutionen einfließen lassen. Um solch eine neue Wissenschaftstheorie, die zugleich eine neue Wissenschaftsgeschichte sein sollte, zu begründen, bedurfte es nicht nur neuer Begriffe wie „Paradigma“, sondern Kuhn erhoffte sich auch, dass neue historiographische Werkzeuge das Argument und den Befund der wissenschaftlichen Revolution im Plural würden stärken können. Die wissenschaftliche Revolution war kein fernliegendes Ereignis der frühen Neuzeit mehr, sondern ein auch in der Gegenwart stattfindender und durch die Geschichte nachweisbarer Gang einer jeden Wissenschaftsentwicklung.

15 Kuhn (1976), S. 23. 
Wie aber geht Kuhn im Buch selbst vor? Im Grunde seien Wissenschaftler „verständige Menschen“, die auch praktisch und nüchtern agieren könnten. ${ }^{16}$ Doch spielten der Glaube und das intuitive Vorgehen im Wissenschaftsprozess eine große Rolle und damit ein irrationales und unbewusstes Moment: "Wenn also in den Wissenschaften Wahrnehmungsverschiebungen die Paradigmenwechsel begleiten, können wir von den Wissenschaftlern nicht erwarten, daß sie diese Veränderungen unmittelbar bezeugen. ${ }^{\text {17 }}$ Im Moment der Verschiebung kann die Verschiebung selbst nicht dokumentiert werden. Aber vielleicht retrospektiv? Immerhin könnten Wissenschaftler erkennen, wenn etwas akut im Argen liegt, wie Einstein, den Kuhn mit den folgenden Worten aus den autobiographischen Schilderungen von 1949 zitiert: „Es war, wie wenn einem der Boden unter den Füßen weggezogen worden wäre, ohne daß sich irgendwo fester Grund zeigte, auf den man hätte bauen können. ${ }^{18}$ Kuhn führt wenige Zeilen später auch Wolfgang Pauli aus den 1920er Jahren an: „,Zur Zeit ist die Physik wieder einmal furchtbar durcheinander. Auf jeden Fall ist sie für mich zu schwierig und ich wünschte, ich wäre Filmschauspieler oder etwas Ähnliches und hätte von der Physik nie etwas gehört.' Dieses Zeugnis“ - so Kuhn weiter - „ist besonders eindrucksvoll, wenn man es Paulis Worten nach weniger als fünf Monaten gegenüberstellt: ,Heisenbergs Modell der Mechanik hat mir wieder Hoffnung und Freude am Leben gegeben. Es gibt sicherlich noch nicht des Rätsels Lösung, aber ich glaube, es ist jetzt wieder möglich, voranzukommen.“ Und Kuhn kommentiert: „Solche ausdrücklichen Eingeständnisse eines Zusammenbruchs sind äußerst selten. ${ }^{{ }^{19}}$ Aber gibt es vielleicht eine Möglichkeit, im Nachhinein, im Bewusstsein des Vorher und des Nachher, diese Phase innerhalb einer Wissenschaft zu kommentieren? Als Kuhn auf den Übergang von der Newtonschen Mechanik zur Quantenmechanik und auf die diesbezügliche, immer noch nicht abgeschlossene Diskussion zu sprechen kommt, schreibt er: „Es leben heute noch Menschen, die sich an ähnliche Auseinandersetzungen erinnern können, welche durch die Maxwellsche Theorie des Elektromagnetismus und durch die statistische Mechanik hervorgerufen wurden. ${ }^{\prime 20}$ „Es leben heute noch Menschen“ bedeutet zunächst, dass die hier geschilderte physikalische Entwicklung noch nicht lange zurückliegt; es bedeutet aber auch, dass diese Menschen gegebenenfalls zu konsultieren sind.

\footnotetext{
16 Ebd., S. 169, S. 168.

17 Ebd., S. $126 \mathrm{f}$.

18 Ebd., S. $96 \mathrm{f}$.

19 Ebd., S. 97.

20 Ebd., S. 62.
} 


\section{Das Interview}

Der Vorgang der Revolution, der Paradigmenwechsel selbst ist nicht zu berichten, aber kann doch in Teilen erinnert oder, in Kuhns Worten, „bezeugt“ werden. Im Frühjahr 1962 hoffte er, solche Zeugnisse - oder wie er sie an anderer Stelle nennt: „authentische Informationen“21 - durch eine umfassende Befragung derjenigen gewinnen zu können, die an den physikalischen Revolutionen zu Beginn des 20. Jahrhunderts beteiligt gewesen waren und die er die „living sources“ nannte. ${ }^{22}$ Im Februar 1962 richtete das Projekt einen an 180 Physiker $^{23}$ im In- und Ausland verschickten Aufruf: (Abb. 2) „An Appeal for Letters, Manuscripts and Recollections“. Wenig sei über die Entwicklung der theoretischen Physik bekannt; wenig „of the battles of mind in the decisive period has been described.“ Solche Dokumente seien wertvoll „for analyzing the scientific method in action".

"Only those involved know who influenced whom and how and why in the formulation of quantum physics." Man sammle Briefe, Manuskripte, Protokolle von Treffen, Photographien und Filme sowie „recollections of seminars where critical steps were discussed; of moments at which an important concept emerged; and of occasions when the outlook of one investigator was dramatically changed by another." Es kam ihnen also auf die Momente an, die Augenblicke, in denen sich etwas grundlegend geändert hatte. „It is already nearly too late to undertake a project with these aims. Its success will depend upon the active cooperation of the physics profession. “24

Auch wenn man noch nicht genau wusste, wie die Erinnerungen sammelnden Interviews auszusehen hatten, so war man sich doch darin einig, dass sie keinem journalistischen, flüchtig geführten und womöglich fehlerhaft wiedergegebenen Interview ähneln sollten. John Wheeler fand dafür deutliche Worte: "Bohr telling history of physics to a LIFE reporter - or Bohr telling physics to a physics graduate student, even a very good physics graduate student is totally different from Bohr telling history to George Uhlenbeck". ${ }^{25}$ Niels Bohr würde - zuvorkommend und freundlich wie er von seinen Zeitgenossen wahrgenommen wurde - einem LIFE-Reporter und auch einem Studenten

21 Ebd., S. 148.

22 APS, AHQP, BOX 22-530.1AR2.5.: „Replies to Priority List Oct. 16, 1961“.

23 So in einem Schreiben an die Mitglieder des Joint Committee vom 26.4.1962; APS, AHQP, BOX 23-530.1AR2.5.: „Progress Report“, S. 1.

24 "Appeal” in APS, AHQP, BOX 22-530.1AR2.5: „Description of Project, November, 1961“.

25 APS, John Wheeler Papers (im Folgenden JWP), Series I: Princeton Files, Sources for History of Quantum Physics, Box 26: B: W 564: „Aug. 1960-Apr.1961“, Brief von Wheeler an das Ad Hoc Committee vom 9.2.1961, S. 3 . 


\section{An Appeal for Letters, Manuscripts, and Recollections}

In June 1961 the American Physical Society and the American Philosophical Society applied through a joint committee to the U. S. National Science Foundation for a three-year grant "to record interviews with men central in the 1913-1938 quantum revolution and to retrieve documentary material on quantum theory and related scientific developments, 1898-1938." The letter of application emphasized that, though quantum physics is the center of a revolution in scientific theory without parallel in modern times, the details of its development are largely unknown. Little of the battle of minds in the decisive period has been described, and even the records from which such a description might be drawn are fragmentary. Only those involved know who influenced whom and how and why in the formulation of quantum physics.

Records that can provide answers to questions like these are today recognized as vital for understanding what quantum physics has become, for analyzing the scientific method in action, and for providing the source materials essential to books on physics and its history. Recognizing the urgent need for such records the National Science Foundation made - through the American Institute of Physics-a grant to support their collection. Intensive exploratory research has been in progress since July 1961 under the direction of Thomas S. Kuhn (Ph.D. in physics, Harvard 1949, now Professor of the History of Science at the University of California, Berkeley). That work is being guided by the original sponsoring committee under the chairmanship of J. A. Wheeler of Princeton University. The other members are: K. K. Darrow, G. Holton, F. Seitz, G. E. Uhlenbeck, and J. H. Van Vleck for the Physical Society; and H. A. Moe, G. W. Corner, and R. H. Shryock for the Philosophical Society. Professors Bohr, Born, Goudsmit, Rosenfeld, Segrè, and Wigner have already promised their active cooperation. This notice is to solicit assistance from a wider circle.

The project particularly desires information about:

(1) letters bearing on the history of quantum physics

(2) manuscript materials

(3) records of meetings

(4) photographs and films

(5) recollections of seminars where critical steps were discussed; of moments at which an important concept emerged; and of occasions when the outlook of one investigator was dramatically changed by another.
Copies of such documents or accounts of such recollections will be gratefully received, but what is particularly requested at this time is word of their existence and whereabouts.

The project aims to insure the preservation of all such materials, the originals at suitable local archives and copies at a few major research centers. Even more urgently it intends to record recollections and commentary of the surviving participants in the development of quantum physics and of their close associates. As its final goal the project will publish a catalogue of the materials it has located or collected. The libraries of the American Philosophical Society in Philadelphia and of the University of California, Berkeley, have volunteered their excellent facilities for the deposit and circulation to scholars of the project's tape, microfilms, and, where suitable, original manuscripts. Close liaison, including exchange of relevant materials, is being maintained with the American Institute of Physics' project on the History of Recent Physics in the United States.

Since late last summer a close study of the existing published record-technical, biographical, and historicalhas been in progress at Berkeley. One aspect of the work has been the preparation of schematic biographies and bibliographies of more than one hundred participants in the development of quantum physics. Tape-recorded interviews with a few of those individuals will begin experimentally during the spring of 1962 and continue intensively during the summer. In September the project will move to headquarters in Copenhagen to facilitate work with European scientists.

It is already nearly too late to undertake a project with these aims. Its success will depend upon the active cooperation of the physics profession. Readers are therefore urged to respond and to bring this notice to the attention of others who may be helpful. Until September 1962 suggestions and information about source materials should be sent to Professor Thomas S. Kuhn at 224 Stephens Memorial Hall, University of California, Berkeley 4, California. During the year following, the project's address will be: Universitetets Institut for Teoretisk Fysik, Bleg. damsvej 17, Copenhagen, Denmark.

BERKELEY, CALIFORNIA, FEBRUARY 1962

ABB. 2

Aufruf von 1962

geduldig Fragen beantworten. Aber er könnte sicher eine vollständigere und detailliertere Antwort geben, wenn er von Fachkollegen interviewt würde. Es würde an dieser Stelle zu weit führen, die verschiedenen Auffassungen von einem Interview um 1960 - einem guten wie einem schlechten - aufzuzählen. Dass das journalistische, in dieser Zeit oftmals als sensationsheischend 
wahrgenommene Interview abgelehnt wurde, verwundert nicht. Es ging vielmehr um die Gewinnung belastbaren Materials, im Falle der Geschichte eben um valide Quellen. Blickt man deshalb auf die Geschichte des Forschungsinterviews, so kann man von einer "Test-Tradition“ und einer "klinischen Tradition“ sprechen. Während die „Test-Tradition“ auf Fragereihen, deren Beantwortung und schließlich die statistische Auswertung der Messergebnisse rekurrierte, kann die „klinische Tradition“ durch das Führen von Tiefeninterviews und deren anschließende Auswertung gekennzeichnet werden. In beiden Fällen war die Hoffnung auf valides, weil quantifizierbares wie interpretierbares Material geschürt worden und suggerierte vor allem eines: eine erfolgreiche Datensammlung. ${ }^{26}$ Doch welche Art von Interview hatte man um 1960 bereits mit Physikern geführt, was waren die Vorbilder, an denen Kuhn und seine Mitstreiter sich orientieren konnten?

Die führenden Physiker waren immer wieder zu Tagesereignissen, zu neueren physikalischen Entwicklungen und zu deren politischer Bedeutung befragt worden. I. Bernhard Cohen, selbst Wissenschaftshistoriker, führte etwa kurz vor dem Tod Einsteins 1955 ein Interview mit dem Physiker in Princeton. Die im Scientific American erschienene Darstellung glich einem written-up interview oder einer interview story, die mindestens genauso viel über die Umgebung und Wohnung Einsteins, über seinen Habitus und seine Kleidung berichtete wie über seine Arbeit als Physiker. ${ }^{27}$ Zwar waren mündliche Sentenzen wiedergegeben worden, doch hatte Cohen in der Tat eine zusammenhängende, einer Reportage vergleichbare Schilderung seines Aufenthalts im Hause Einsteins daraus gemacht. Kuhn wird dieses Interview gekannt haben. Doch sicher war ihm noch ein weiteres, bereits publiziertes Beispiel vor Augen: 1958 war die Übersetzung von Robert Jungks Buch zur Geschichte der Atomforschung und der Entwicklung der Atombombe auf dem amerikanischen Buchmarkt unter dem Titel Brighter than a Thousand Suns erschienen. Edward Uhler Condon, selbst kurze Zeit Mitarbeiter von Robert Oppenheimer im Manhattan Project,

26 Eine Darstellung der Geschichte des Forschungsinterviews würde den Rahmen dieses Aufsatzes sprengen. Vgl. dazu überblickend te Heesen (2013) sowie die eingangs erwähnte Monographie zu Kuhn und dem Projekt, die sich in Vorbereitung befindet. Wertvoll ist die Beschreibung der Entwicklungspsychologin Eleanor E. Maccoby und des Psychologen Nathan Maccoby von 1954 (Maccoby/Maccoby [1976]), der auch die Begriffe der „Test-Tradition“ und der „klinischen Tradition“ entnommen sind sowie die immer noch lesenswerte „Geschichte der Soziographie“ von Hans Zeisel, einem der Mitarbeiter der Marienthal-Studie von 1933 (Zeisel [1975]); für einen Überblick über die Hand- und Lehrbücher des Interviews siehe Jennifer Platt (2002).

27 Cohen (1955) und zu den Begriffen „interview story“ und „written-up interview“ vgl. Ruchatz (2014), S. 92-101. 
beginnt seine vernichtende Kritik des Buches in der Zeitschrift Science 1958 mit den Worten: „This is a thorougly bad book which is so interestingly written that it is sure to be widely read, and thus to make a large contribution to spreading confusion and erroneous views about its subject. ${ }^{228}$ Jungks Buch kann als eine Art Vorgängerunternehmen bezeichnet werden, auf das die Protagonisten zwar kaum Bezug nahmen, das die Bedeutung der "Sources“ aber umso deutlicher machte. Jungk hatte sich zum Ziel gesetzt, auf die Schrecken der Atombombe aufmerksam zu machen. Zunächst hatte Jungk erwogen, einen Roman über deren Entwicklung und ersten Einsatz zu schreiben. Die Zweifel der Kernphysiker und das moralische Dilemma von Forschung und Anwendung wie deren Folgen sollten im Mittelpunkt seines Buches stehen.

Um diesen Roman lebensecht zu gestalten, mußte ich beginnen, die wirklichen Hintergründe dieser Karriere zu studieren. Der erste bedeutende Kernphysiker, den ich nun traf, war der an der Universität Bern lehrende Professor Fritz Houtermans. Das war ein Glücksfall. Denn im Gegensatz zu vielen seiner Kollegen, die mehr in der Welt der Formeln als der Anekdoten leben, mehr in der Zukunft als in der Vergangenheit, wußte Houtermans auf lebendige und spannende Weise [...] zu erzählen. ${ }^{29}$

Die Begegnung mit Houtermans und dessen Bereitschaft „zu erzählen“ bewirken bei Jungk die Erkenntnis:

Kein Roman konnte die tatsächliche, durch Aussagen und Dokumente belegbare Tragödie der Atomforscher an Bedeutsamkeit, Eindringlichkeit und Spannung übertreffen. Als ich Houtermans verließ, wußte ich, daß ich die Elemente meines Buches nicht in meiner Phantasie finden würde, sondern nur durch genaueste Befragung aller noch erreichbaren Menschen, die jenes für unsere Zeit so kennzeichnende Drama gelebt hatten. ${ }^{30}$

Das ganze Buch hindurch werden diese Befragungen zitiert und in den Gang der Darstellung durch Kenntlichmachung der wörtlichen Rede eingeflochten. Jungk wurde in den Kritiken zwar sein verständliches humanitäres, weil auf die Gefahren des Atomzeitalters hinweisendes Engagement in der Sache zugutegehalten, die korrekte Darstellung der eigentlichen Ereignisse wurde aber

\footnotetext{
28 Condon (1958), S. 1619 .

29 Jungk (1956), S. $11 \mathrm{f}$.

30 Ebd., S. 12.
} 
infrage gestellt. Blickt man in den "Dank des Verfassers“, erkennt man schnell, dass die Liste der von ihm für dieses Projekt interviewten Personen mit der Kuhns und seiner Mitstreiter viele Überschneidungen enthält. ${ }^{31}$ Doch für Kuhn war das Vorgehen des Journalisten nicht satisfaktionsfähig. Auch wenn er die Bedenken Jungks vielleicht teilte, so ging es nicht um romanhaften Überzeugungs-Dokumentarismus, wie er in den 1950er, vor allem aber in den 196oer Jahren in der Gegenwartsliteratur auftauchte, sondern um die Erstellung einer möglichst lückenlosen Chronologie der Entwicklung einer ganzen, das Weltbild des 20. Jahrhunderts verändernden Disziplin und ihrer Protagonisten. Das buzzword der Zeit lautete vielmehr Oral History.

\section{Die Oral History}

Vermutlich wurde Kuhn von Richard Shryock, dem leitenden Bibliothekar der American Philosophical Society, auf die Oral History und einen ihrer zum damaligen Zeitpunkt prominentesten Vertreter, Saul Benison in New York, hingewiesen. Bei Benison hatte er sich früh Ratschläge geholt. Am 20.7.1961, drei Wochen nach dem offiziellen Projektbeginn, besuchte er den Historiker in New York und führte ein langes Gespräch mit ihm. In den nachfolgenden Monaten tauschten sie immer wieder Briefe aus. Benison war seit 1953 „Research Associate of Columbia University's Oral History Research Office“. Das Büro wurde von Allan Nevins, dem Begründer der Oral History, 1948 ins Leben gerufen und beschäftigte sich mit dem biographischen Interview als einer Schlüsselmethode der historischen Forschung. Nevins wurde 1958 emeritiert und Kuhn hätte niemand Erfahreneren als Benison, einen Schüler Nevins', finden können. Benison war auch deshalb ein naheliegender Ansprechpartner, weil er sich in seinen biographischen Forschungen vor allem Medizinern und Wissenschaftlern widmete. Und so gab er konkrete Ratschläge und Anweisungen, wie zu interviewen sei. „Ever since I returned to Berkeley I have been cogitating your advice about interviewing“, schrieb Kuhn am 21. August 1961.

In particular, your estimate of the very limited number of tape-hours that any interviewer can compile in a year has been doing much to re-shape my thinking about the project. Clearly we must either have more staff, reduce preparation (which you and I agree we ought not do), or reduce our number of subjects very considerably. ${ }^{32}$

$31 \quad$ Ebd., S. 7 f.

32 Brief von Kuhn an Benison, 21.8.1961, APS, AHQP, BOX 17-530.1AR2.5: „General Correspondence A-Z 1961-1962“. 
Wie wichtig die ausführliche Vorbereitung eines solchen Interviews war, wird in einem Brief von Benison an Kuhn vom 8.1.1962 deutlich: "If it is the difference between getting a man while he is still alive or missing him entirely I say miss him rather than to talk with him without adequate preparation." ${ }^{33} \mathrm{Am}$ Ende des Briefes fügte er in einem handschriftlichen Postskriptum hinzu: „A paper which will appear in Isis in March gives more detail on the process. ${ }^{\text {“34 }}$ Liest man diesen beiläufig erwähnten Aufsatz, Notes on Oral Interviewing, so kann man den Eindruck gewinnen, dass das gesamte Sources-Project nach diesen Anweisungen gestaltet wurde. ${ }^{35}$ Wiederholt weist Benison dort auf eine nötige umfangreiche Vorbereitung der Befragung hin. Er betont das Einholen von primären und sekundären Quellen, die nicht nur der Vorbereitung des Interviewers dienen sollen, sondern auch dazu, die Erinnerung der Befragten aufzufrischen. Die so entstehenden "Memoirs“ seien das Ziel der Oral History. Biographie um Biographie sollte in dieser Form gesammelt werden, um dem Verschwinden der Zeit zu begegnen. ${ }^{36}$ Denn, so Benison, es gingen nicht nur Dokumente beständig verloren, vielmehr würden nach der Kommunikationsrevolution gar keine mehr generiert. In dem Moment, wo die Techniken uns in Stand setzten, möglichst viel aufzuschreiben, würden die Zeugnisse immer weniger: Telefon und Flugzeug förderten das verbale Gespräch, aber keines auf dem Papier. Dies sei der eigentliche Grund für die zentrale Bedeutung der Oral History. ${ }^{37}$ Das in den nachfolgenden Jahren zum Gemeinplatz werdende Argument war der Hebel, mit dem die Befragung von wichtigen, an zentralen Entwicklungen in Gesellschaft und Wissenschaft beteiligten Personen initiiert und finanziert werden sollte: Präsidenten, Firmengründer und Professoren. Die frühe Oral History war keine Geschichte der kleinen Leute, die denjenigen eine ,Stimme verleihen sollte, die sich ansonsten nicht würden äußern können, sondern eine Geschichte derjenigen, deren Erinnerung als unbedingt aufbewahrungswürdig erachtet wurde und deren entscheidende Gedanken und Taten bisher nicht genügend archiviert worden waren. ${ }^{38}$ Diese Oral History nahm deshalb in ihrer Interviewtechnik weniger Anleihen bei der damaligen

33 Brief von Benison an Kuhn, 8.1.1962, in ebd.

34 Ebd.

35 Vgl. dazu die Notes of Oral Interviewing, in denen er sein Gespräch mit Benison offiziell festhält. APS, AHQP, BOX 22-530.1AR2.5: „Notes on Interviewing Methods“.

36 Benison (1962), S. 114 f.

37 Ebd., S., $113 \mathrm{f}$.

38 Vgl. hierzu Niethammer (1978), S. 463-468 in Bezug auf Presidential Libraries; vgl. auch den informativen Überblick bei Sharpless (2006) sowie Seldon (1996), der das „elite interviewing" als "the black sheep among the contemporary historian's sources" bezeichnet (S. 353); überblickend zur amerikanischen Oral History und ihrer Entwicklung Dunaway/ Baum (1996). 
Sozialforschung oder dem klinischen Interview. Vielmehr war sie als Ergänzung, als Quellendefizite ausgleichendes Verfahren gedacht. ${ }^{39}$

In seiner später erschienenen Darstellung des Mediziners und Virologen Tom Rivers, an der er bereits während der Beratung Kuhns gearbeitet hatte, gibt Benison eine individualisierte Darstellung dieser Techniken: Wieder stehen hier die sorgfältigen Vorbereitungen im Vordergrund, doch jetzt wird der tatsächliche Aufwand deutlich. Nach jedem Interview mit Rivers habe er ihn darauf hingewiesen, was im nächsten Interview erfragt würde, und Rivers vorbereitend mit schriftlichem Material ausgestattet, "that might serve to refresh his memory“. ${ }^{40}$ Rivers wiederum gab Benison Hinweise auf Literatur und weitere Informationen. Bei den Gesprächen lag dieses Material bereit, sodass beide jederzeit darauf zurückgreifen konnten. Bei einigen Gelegenheiten habe Rivers aus den zuhandenen Dokumenten zitiert oder darum gebeten, dass dieses Material in das spätere Memoir einfließen solle. Wenn ein Interview zu einem bestimmten Themenkomplex abgeschlossen gewesen sei, habe Benison ihm das Transkript zur Korrektur gegeben. ${ }^{41}$ Nachdem Rivers vor der Fertigstellung des gesamten Memoirs gestorben war, gab Benison die einzelnen fertiggestellten Teile an frühere Kollegen weiter und bat sie um kritische Kommentare. Folgt man den minutiösen Beschreibungen Benisons, so wird deutlich, dass es zwar um die Konservierung von persönlichen Redewendungen oder um die authentischen Schilderungen von Rivers ging, ${ }^{42}$ dass aber zugleich der aktive Versuch unternommen wurde, ihm ein lückenloses Lebensmosaik (in den Mund) zu legen. Oral History im Verständnis der beginnenden 196oer Jahre war das rastlose Zusammenfügen von einem aus verschiedenen Medien bestehenden Quellenteppich, den es ordentlich zu weben galt: „While the end product of oral history often looks neat and logical, the process itself isn't, because man's memory and the course of conversation are frequently untidy. ${ }^{43}$ Dies bedeutet nichts anderes, als dass die Unordnung des gelebten Lebens in eine chronologische und gleichmäßige Berichtsordnung zum Zwecke der Konservierung der modernen Welt überführt werden musste. Es ist also das

39 Niethammer (1978), S. 465. Vgl. dazu die interessante rückblickende Schilderung von Niethammer (2017), S. 111-113. Den Hinweis auf dieses Interview verdanke ich Franka Maubach.

$40 \quad$ Benison (1967), S. xii.

41 Ebd., S. xiii.

42 „Errors of fact and interpretation, even when known to be errors, were kept because such mistakes were often revealing of the man and his thought. These I have footnoted passim." (Ebd., S. xiii)

43 Ebd., S. xii. 
Ideal des auf Ordnung bedachten Verfahrens für die Hervorbringung von Erinnerung an die unordentlich verlaufende Forschung, die am Anfang der „Sources" steht.

Was konnte für den Autor der Structure verheißungsvoller sein, als der zwar arbeitsaufwändige, aber dennoch lohnenswerte Versuch, die Vergangenheit mit der Hilfe von Einzelpersonen und deren Lebensgeschichten zu konservieren und dabei den Umschlagsmomenten der wissenschaftlichen Revolutionen weiter auf die Spur zu kommen? Die Oral History verhieß zu Beginn der 196oer Jahre vor allem Quellenergänzung, die in Kuhn die Hoffnung geschürt haben mag, dass es retrospektive Betrachtungsmöglichkeiten für frühere Paradigmenwechsel geben könnte. Wenn man aber so nahe an das Geschehen herankommen könnte, sollte dann nicht eine neue Wissenschaftsgeschichte, unterstützt durch psychologische Techniken und die kleinschrittige Arbeit sorgfältig in der Physik ausgebildeter Historiker-Befrager möglich sein? Konnte man dann nicht in den kollektiven Kopf der Quantenphysik schauen, der plötzlich zu einem riesigen historischen Labor werden würde? Doch die Archivalien des Projekts zeigen heute die wachsende Enttäuschung über die Interviews. In einem ersten „Informal Progress Report“ vom 26. April 1962 wurde über die bis dahin geleistete Arbeit berichtet. Dazu gehörte die Auflistung der ersten Interviews, die seit Februar geführt worden waren. „Together these interviews total about 30 hours of tape or about 500 double-spaced pages of draft transcript. All the tapes include at least some new and valuable historical information, though its average density is not, and probably never will be, extremely high. ${ }^{44}$ Nach den ersten Interviews und insgesamt zehn Projektmonaten tauchten erste Bedenken an der Aussagekraft der Antworten auf: „There is an immense variation in the useful memory of even the most willing subjects. As a result, it proves important to try out a number of people but to commit ourselves for much time in advance to none. ${ }^{45}$ Wo nichts erwartet werden kann, soll auch nicht investiert werden. Das Interview, das Thomas S. Kuhn und George Uhlenbeck mit dem Physiker und Chemiker Peter Debye am Rockefeller Institute an einem Nachmittag im Mai 1962 führten, mag ein konzentriertes Beispiel dafür sein, dass der Eindruck nur allzu spärlicher Ergebnisse überwiegen musste. Debye wird nach seiner Zeit in Deutschland befragt, insbesondere nach seiner Zeit bei dem theoretischen Physiker Arnold Sommerfeld in München. Im Mittelpunkt steht die Frage, wann erste intensive Diskussionen um die Relativitätstheorie aufkamen.

44 APS, AHQP, BOX 23-530.1AR2.5: „Progress Report April 26, 1962“, Progress Report, S. 3.

45 Ebd., S. 4. 
UHL: Now the relativity theory of course not yet so far.

D: No, no, no. So he [Sommerfeld, AtH] was very much interested in it, and accepted it right away, you see, but that was all, so to say.

TSK: You didn't have discussions then, that you remember, of relativity theory as early as the 1905 paper of Einstein?

D: Oh yes, when the paper came out we had discussions about it, but that was just to say, ,Well this is all right.' There was nothing to it.

UHL: Nothing about the paradoxes and so forth?

D: No, no, well, the few paradoxes - we went over that very easily. This was not like the paradoxes later with Einstein and quantum theory.

UHL: No, no, but I mean some of the simultaneity paradoxes.

D:Yes, yes, well we accepted that rather easily. It was not hard to accept it. After all we had Lorentz's transformation, and then it was just a question of philosophical interpretation of the Lorentz transformation. That was all.

TSK: Was Sommerfeld pretty well convinced already that there was no need for a mechanical aether or anything of this sort?

D: Oh yes, oh yes, right from the beginning. We didn't bother about that. I had enough of that in this course of Wöllner, you know. No no, that was done approximately like as if the equations came from heaven, you see. ${ }^{4} 6$

Mit Gleichungen, die vom Himmel fallen konnten, würden keine näheren Umstände beschrieben. Kein Moment der Verwunderung, keine Erinnerung an ausführliche Diskussionen, die das Für und Wider einer Gleichung hätten vorführen können, sondern vielmehr eine Erzählung von sukzessive sich einstellenden Erkenntnissen. Mit Peter Debye hatte man im Frühjahr 1962 insgesamt 4 Stunden und 30 Minuten gesprochen..$^{47}$ Kuhn kommentiert dieses Interview wie folgt: „Professor Debye's remarks on the reception of the Bohr atom are quite explicitly a reconstruction of how things must have been or ought to have been. As such, they are entirely lacking in the sort of circumstantial detail which would make them either useful or entirely credible." ${ }^{48}$ Im „First Year-End Report" zitiert er deshalb aus dem Debye-Interview, um die Probleme, das Fehlen von "circumstantial details“, zu beschreiben und in nuce vorzuführen. Auch wenn Kuhn mehrfach betonte, dass es einige wenige gute Interviews gebe, so machte er zugleich ein Jahr später deutlich, dass

46 APS, AHQP, Box 23-530.1AR2.5: „First Year-End Report August 8, 1962“, Attachment III, S. 2.

47 Ebd., Attachment II, S. 1.

48 Ebd., S. 3. 
er hier kein lohnenswertes Arbeitsfeld mehr sehe. In einem Brief an George Uhlenbeck, mit dem er ein Jahr zuvor das zitierte Debye-Interview geführt hatte, schrieb er 1963: „To put first the point about which I am most nearly certain, I would not recommend that the Committee plan to continue this project on its present scale“. ${ }^{49}$ Kuhn empfiehlt aus den vielen Personen, die sie interviewt hatten, einige wenige auszuwählen und mit ihnen lange "full-scale“ Interviews in der Art des Columbia Oral History Projects zu führen. ${ }^{50}$ Während ganz zu Beginn des Projekts noch Hoffnung auf präzise Angaben über einen Entdeckungszeitraum bestand, schlug er nun die Aufzeichnung der Lebensgeschichte der exemplarischen und großen Männer vor. Und so gesteht Kuhn zwar im „Second Year-End Report“ von Oktober 1963 ein, dass Interviews wertvolle biographische und milieubezogene Informationen für den Historiker liefern könnten, dass sie aber nicht für "significant information" taugten:

And on substantive issues we continue to find that very few of our subjects can supply much significant information. Almost no one is able to tell us very much about the sources of new ideas and problems, the difficulties encountered in developing them, and their reception by the physics community. ${ }^{51}$

Der Gang der Entdeckung, die Unlogik der Forschung, die Kontingenz und persönliche Gefühle, nichts oder nur wenig von alledem kam in den Befragungen zum Vorschein. Die Erinnerungen der befragten Protagonisten richteten sich auf große Ereignisse (Konferenzen), auf Atmosphären (das Berliner Kolloquium) oder auf die nachträglich bestätigten Entdeckungsschritte. Kuhns Enttäuschung bestand deshalb darin, dass die Protagonisten der Zeit mit ihrem Blick zurück den der Nachfolgenden reproduzierten, dass ihre Erinnerungen von den Darstellungen der Lehrbücher überdeckt worden waren. Zusammenfassend kann deshalb festgehalten werden, dass die Tradition des Elite-Interviews, der Rekonstruktion des lückenlosen Lebensteppichs nicht auf Fehler ausgelegt war, sondern auf den chronologischen Lauf des "guten Lebens“. Nicht Brüche, sondern Kontinuitäten, nicht Sackgassen, sondern das Erreichen der nächst höheren Erkenntnis- und Karrierestufe standen im Vordergrund. Der vieldeutig auslegbare Begriff des „Memoirs“ in der frühen Oral History muss deshalb als lebensgeschichtliche Darstellung von Fortschritt und Erfolg des Einzelnen verstanden werden. Doch weder verstand sich Kuhn als Memoirenschreiber,

49 APS, AHQP, BOX 23-530.1AR2.5: „Letter to Geo. E. Uhlenbeck 10/18/63“, S. 1.

5o Vgl. hierzu auch den Abschnitt „Lebensgeschichte und Sozialkultur“ im Text von Franka Maubach in diesem Heft. 
noch wurde er für seine Mühen mit Erkenntnissen zu den Umschlagspunkten der Wissenschaft belohnt. Die große Hoffnung auf die noch nicht ausgeschöpfte Informationsquelle des wissenschaftlichen Entdeckungsvorgangs, die mehr über die Prozesse des Forschens würde aussagen können, hatte sich nicht erfüllt. Kehrt man zum Ausgangspunkt des vorliegenden Textes zurück, so zeigt das eingangs beschriebene Zeitungsbild den Leiter des Projekts, der den Sinn des Unternehmens 1963 vor allem in der Sammlung und Kopie der Notizen, Briefe und Manuskripte der alten Physiker sah, zum allerwenigsten aber in den Befragungen selbst. Was er also im damaligen Büro vor sich liegen hatte, waren vermutlich keine Interviewtranskripte.

\section{Literatur}

Baltas, Aristides/Gavroglu, Kostas/Kindi, Vassiliki (2000): „A Discussion with Thomas S. Kuhn", in: Thomas S. Kuhn (Hg.), The Road since Structure. Philosophical Essays, 1970-1993, with an Autobiographical Interview, ed. by J. Conant and J. Haugeland. Chicago/London: University of Chicago Press, S. 254-323.

Benison, Saul (1962): „Oral History and Manuscript Collecting“, in: ISIS 53/1 (1962), S. 113-117.

Benison, Saul (1967): Tom Rivers. Reflections on a Life in Medicine and Science. An Oral History Memoir prepared by Saul Benison. Cambridge (Mass.)/London: M.I.T. Press.

Carson, Cathry/Kojevnikov, Alexei/Trischler, Helmut (Hg.) (2011): Weimar Culture and Quantum Mechanics. Selected Papers by Paul Forman and Contemporary Perspectives on the Forman Thesis. London: Imperial College Press.

Cohen, I. Bernhard (1955): „An Interview with Einstein“, in: Scientific American 193 (July 1955), S. 68-73.

Condon, Edward U. (1958): "Review of Brighter Than a Thousand Suns. A Personal History of the Atomic Scientists, by Robert Jungk", in: Science 128, 26 (December 1958), S. 1619-1620.

Dunaway, David K./Baum, Willa K. (Hg.) (1996 [zuerst 1984]): Oral History. An Interdisciplinary Anthology. Walnut Creek u.a.: Altamira Press.

Fuller, Steve (2000): Thomas Kuhn. A Philosophical History for Our Times. Chicago/ London: University of Chicago Press.

te Heesen, Anke (2013): „Naturgeschichte des Interviews“, in: Merkur. Deutsche Zeitschrift für Europäisches Denken 67/4 (2013), S. 317-328.

Heilbron, John L. (1968): „Quantum Historiography and the Archive for History of Quantum Physics“, in: History of Science 7 (1968), S. 90-111.

Heilbron, John L./Kuhn, Thomas S. (1969): „The Genesis of the Bohr Atom“, in: Historical Studies in the Physical Sciences 1 (1969), S. vi; 211-290. 
Jungk, Robert (1956): Heller als tausend Sonnen. Das Schicksal der Atomforscher. Bern/ Stuttgart: Scherz Verlag.

Kuhn, Thomas S. (1976 [zuerst engl. 1962]): Die Struktur wissenschaftlicher Revolutionen. Frankfurt am Main: Suhrkamp.

Kuhn, Thomas S./Heilbron, John L./Forman, Paul/Allen, Lini (Hg.) (1967): Sources for History of Quantum Physics. An Inventory and Report. Philadephia: The American Philosophical Society.

Maccoby, Eleanor E./Maccoby, Nathan (1976): „Das Interview: Ein Werkzeug der Sozialforschung“, in: René König (Hg.), Das Interview. Formen, Technik, Auswertung. Köln: Kiepenheuer \& Witsch, 10. Aufl., S. 37-85.

Niethammer, Lutz (1978): „Oral History in den USA. Zur Entwicklung und Problematik diachroner Befragungen“, in: Archiv für Sozialgeschichte 18 (1978), S. 457-501.

Niethammer, Lutz (2017): „Oral History in der deutschen Zeitgeschichte. Lutz Niethammer im Gespräch mit Veronika Settele und Paul Nolte“, in: Geschichte und Gesellschaft 43 (2017), S. 110-145.

Platt, Jennifer (2002): „The History of the Interview“, in: Jaber F. Gubrium/James A. Holstein (Hg.): Handbook of Interview Research. Context \& Method. Thousand Oaks/ London/New Delhi: Sage Publications, S. 33-54.

Ruchatz, Jens (2014): Die Individualität der Celebrity. Eine Mediengeschichte des Interviews. Konstanz/München: UVK.

Seldon, Anthony (1996): „Elite Interviews“, in: Brian Brivati/Julia Buxton/Anthony Seldon (Hg.): The contemporary history handbook. Manchester/New York: Manchester University Press, S. 353-365.

Sharpless, Rebecca (2006): „The History of Oral History“, in: Thomas L. Charlton/Lois E. Myers/Rebecca Sharpless (Hg.): Handbook of Oral History. Lanham u.a.: Altamira Press, S. 19-42.

Sigurdsson, Skúli (1990): „The Nature of Scientific Knowledge: An Interview with Thomas Kuhn“, in: Harvard Science Review (Winter 1990), S. 18-25.

Zeisel, Hans (1975 [zuerst 1933]): „Zur Geschichte der Soziographie“, in: Marie Jahoda /Paul Felix Lazarsfeld/Hans Zeisel (Hg.), Die Arbeitslosen von Marienthal. Ein soziographischer Versuch. Frankfurt am Main: Suhrkamp Verlag, S. 113-142.

\section{Archivmaterial}

Ich danke der American Philosophical Society für die Abdruckgenehmigung. American Philosophical Society (APS), "Archive for the History of Quantum Physics" (AHQP), BOX 23-530.1AR 2.5: "Second Year-End Report, Oct. 28, 1963". APS, AHQP, BOX 23-530.1AR 2.5: "Correspondence 1964". APS, AHQP, BOX 22-530.1AR2.5.: „Replies to Priority List Oct. 16, 1961“. APS, AHQP, BOX 22-530.1AR2.5: „Description of Project, November, 1961“. 
AP S, John Wheeler Papers (JWP), Series I: Princeton Files, Sources for History of Quantum Physics, Box 26: B: W 564: „Aug. 1960-Apr. 1961“, Brief von Wheeler an das Ad Hoc Committee vom 9.2.1961.

APS, AHQP, BOX 17-530.1AR2.5: „General Correspondence A-Z 1961-1962“, Brief von

Kuhn an Benison, 21.8.1961.

APS, AHQP, BOX 22-530.1AR2.5: "Notes on Interviewing Methods".

APS, AHQP, BOX 23-530.1AR2.5: "Progress Report April 26, 1962", Progress Report.

APS, AHQP, BOX 23-530.1AR2.5: "First Year-End Report August 8, 1962", Attachment III. APS, AHQP, BOX 23-530.1AR2.5: "Letter to Geo. E. Uhlenbeck 10/18/63“.

APS, AHQP, BOX 23-530.1AR2.5: „Second Year-End Report Oct. 28, 1963“.

\section{Abbildungsnachweis}

Abb. 1: Zeitungsausschnitt einer dänischen Zeitung vom Juni 1963 in APS, AHQP, BOX 22-530.1AR 2.5: „Announcement to Scient. Journals“.

Abb. 2: APS, AHQP, BOX 22-530.1AR2.5: „Description of Project, November, 1961“. 